Intervention for Human Rights in Europe 
Also by Janne Haaland Matláry

EMU: A Swedish Perspective (co-author with L. Calmfors et al.)

ENERGY POLICY IN THE EUROPEAN UNION 


\section{Intervention for Human Rights in Europe}

Janne Haaland Matláry

Head, International Politics Section

Department of Political Science

University of Oslo

Norway 


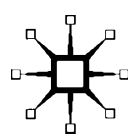

(c) Janne Haaland Matláry 2002

Softcover reprint of the hardcover 1st edition 2002 978-0-333-79424-1

All rights reserved. No reproduction, copy or transmission of this publication may be made without written permission.

No paragraph of this publication may be reproduced, copied or transmitted save with written permission or in accordance with the provisions of the Copyright, Designs and Patents Act 1988, or under the terms of any licence permitting limited copying issued by the Copyright Licensing Agency, 90 Tottenham Court Road, London W1T 4LP.

Any person who does any unauthorised act in relation to this publication may be liable to criminal prosecution and civil claims for damages.

The author has asserted her right to be identified as the author of this work in accordance with the Copyright, Designs and Patents Act 1988.

First published 2002 by

PALGRAVE

Houndmills, Basingstoke, Hampshire RG21 6XS and

175 Fifth Avenue, New York, N.Y. 10010

Companies and representatives throughout the world

PALGRAVE is the new global academic imprint of

St. Martin's Press LLC Scholarly and Reference Division and Palgrave Publishers Ltd (formerly Macmillan Press Ltd).

ISBN 978-1-349-42014-8

DOI 10.1057/9780230504165

ISBN 978-0-230-50416-5 (eBook)

This book is printed on paper suitable for recycling and made from fully managed and sustained forest sources.

A catalogue record for this book is available from the British Library.

A catalogue record for this book is available from the Library of Congress

$\begin{array}{llllllllll}10 & 9 & 8 & 7 & 6 & 5 & 4 & 3 & 2 & 1\end{array}$

$\begin{array}{llllllllll}11 & 10 & 09 & 08 & 07 & 06 & 05 & 04 & 03 & 02\end{array}$ 
To the victims and survivors of the Balkan tragedy - that human rights be theirs 
This page intentionally left blank 


\section{Contents}

Preface

\section{Part I State Sovereignty and Human Rights}

1 Towards a New Type of Sovereignty in Europe 3

$\begin{array}{ll}\text { The new interventionism } & 7\end{array}$

Foreign policy decoupled from territory $\quad 10$

$\begin{array}{ll}\text { Sovereignty: the key principle } & 11\end{array}$

An essential and persistent tension $\quad 15$

$\begin{array}{ll}\text { Power } & 19\end{array}$

Values $\quad 23$

Human rights and security policy 25

'Soft power, hard values' - the argument 28

2 Human Rights and Democracy: Driving Forces and Policy Tools 33

The importance of norms, rules and regimes 34

The importance of legitimacy 40

New actors: the norm entrepreneurs 43

New arenas: multilateral diplomacy and international organisations 48

New transparencies: globalised media and internet $\quad 50$

New supranationality; courts and juridification of

human rights 53

Policy tools of human rights and democracy 56

Conclusion: how strong are the driving forces? 58

3 The Formation of the European Human Rights Regime 60

The precursors 61

Human rights in international politics $\quad 62$

The European human rights regime:

the ECHR and later instruments 
The European human rights regime:

the Helsinki Final Act and later documents 68

The European human rights regime:

the European Union's texts and its charter 76

Copenhagen criteria of conditionality 77

Complementarity of the European human rights regime $\quad 79$

4 The Impact of International Organisations

$\begin{array}{ll}\text { and Regimes } & 81\end{array}$

Status of regime theory $\quad 82$

Impact and how to measure it $\quad 83$

$\begin{array}{ll}\text { Regime impact } & 90\end{array}$

The importance of legality 91

Actors and loci of policy-making $\quad 94$

The impact of values $\quad 95$

Interest formation: instrumental and normative logics 96

The concept of value-based interests 98

Hypotheses and research design 102

Part II The Impact of the Human Rights Regime 109

5 The Impact of the Council of Europe 111

The Council of Europe as a foreign policy actor:

tools and powers 116

Regime-specific tools of the COE 118

The expansion of the COE:

therapeutic admissions and new tasks 119

The impact of the European Court of

Human Rights

The human rights monitoring machinery

and its impact

Conclusion: the impact of the human rights

regime of the $\mathrm{COE}$

6 The Impact of the OSCE 135

The OSCE as a foreign policy actor: tools and powers $\quad 135$

East-West meeting point 136

The OSCE tools of norm implementation 138

Regime-specific tools $\quad 140$

The general foreign policy impact of the OSCE 143

Evolving norm development and impact: the

example of freedom of religion 
Regime impact of a human right: freedom of religion

Regime impact through missions: Bosnia and Albania 154

Regime impact through the HCNM: the Baltic states 156

Regime impact through the ODHIR: Chechnya

and Azerbaijan

Role of states vs. IO powers

Conclusion: the impact of the OSCE's human

rights regime

The EU as a foreign policy actor: tools and powers $\quad 165$

From the EPC to the CFSP 166

The Common Foreign and Security Policy (CFSP) 168

The CFSP evolution as EU foreign policy 169

EU foreign policy embedded in other policy areas $\quad 171$

The Commission's 'task expansion' 176

The general impact of EU foreign policy 178

The human rights regime: embeddedness and

regime tools

183

Human rights impact: the case of Austria 188

Enlargement: the impact of the Commission $\quad 190$

Regime-specific tools: a summary 194

Conclusion: the impact of the EU human rights regime 197

8 Human Rights and Hard Power:

a New Norm for Intervention?

200

Value-based intervention historically 202

The post-war period 205

The 1990s and beyond $\quad 206$

Political vs. legal issues $\quad 209$

Value-based intervention? The cases of Bosnia

and Kosovo

The present period: the politics of human security 224

The human security network: international

agenda-setting for a new norm

\section{Conclusions}

The findings of this study 231

States, IOs and hard power intervention 233

States, IOs and soft power intervention 235 
What impact from the human rights regime? 


\section{Preface}

This study was started during my tenure as State Secretary of Foreign Affairs of Norway, 1997-2000. I was asked by Macmillan - now Palgrave - to write a book on my experiences of the role that human rights seemed to play in international politics, suggested by Norway's extensive engagement in this field - in human rights dialogues with Cuba, Vietnam and China; in our work in the UN Human Rights Commission; and in peace mediation in places like Guatemala, the Middle East and Sri Lanka; and not least in our work as chairman of the Organisation for Security and Cooperation in Europe (OSCE), which it fell to me to work on in particular.

I noticed that although traditional national interests clearly were important drivers in international politics, there was also an independent factor in the human rights discourse, as no one who wanted to be seen as a legitimate actor in the Western world could afford to be criticised on account of non-compliance with human rights standards. In short, all actors - governments and businesses alike - who aspired to a normal standing in Western international politics had to 'talk the talk' of human rights, democracy and the rule of law: and they also had to implement it for no other reason than to avoid being 'shamed' and exposed. This new 'logic' of soft power fascinated me, as it clearly had teeth, and was no longer simply something for festive speeches.

During our year in the chairmanship of the OSCE we had to deal with the very practical implementation of human rights and democracy in new states that aspired to membership and therefore good standing in Western international organisations - the Council of Europe (COE) and most of all, the European Union (EU); and we worked hard at specifying exactly how and by which standards one could 'remake' states into modern, liberal democracies. During this year we also had to deal with the Kosovo crisis, using first the normal 'soft power' approach of sending a field mission to Kosovo, the Kosovo Verification Mission (KVM); and then later, after having exhausted all the 'soft power' tools, resorting to hard power in a military campaign where human rights and humanitarian considerations did in fact play a significant role.

This study investigates the power behind human rights in today's open, public diplomacy, arguing that most actors adopt human rights 
standards and actually implement them for instrumental reasons, although persuasion and learning naturally may take place as well. My findings are, however, consistent with a view of politics where actors have instrumental interests, and where the role of power is just as relevant for 'value politics' as for other types of politics. I investigate the impact of what is termed the 'European human rights regime', which refers to the common values and definitions defined in the EU, the COE and the OSCE. The definitions of human rights, democracy and rule of law defined in the Convention of Human Rights, the Helsinki Final Act and later OSCE documents, as well as in the Treaty on Political Union (TEU) in the EU and its Charter, are all internally consistent, identical and together make up a whole - the European human rights regime.

The growth of public diplomacy introduces a new type of international politics where actors have to engage in human rights and democracy discourse where they have to accept and promote such values; and once engaged in this, they will be exposed if not compliant. The further a new state is from the centre of Western discourse and Western tradition, the less concerned it is with compliance. Some government leaders do not even 'talk the talk' of human rights, and even less, implement its content. However, there are increasingly fewer of those states. It is clear that states that seek membership of Westerndominated international organisations have to 'talk the talk', that is, adopt human rights rhetoric; but they are also forced to implement its contents as they proceed to work with these organisations. The EU has the most stringent standards in its pre-accession programmes, while the OSCE has field missions in place, observing state behaviour from within the state; and the COE has taken on a much more activist role after admitting very many new states from Central and Eastern Europe, and has the legal power vested in its court to impose rule of law and human rights as such.

This study looks at the impact that these central international organisations (IOs) in Europe have in the field of democracy and human rights. There is a new interventionism in Western foreign policy, we argue, one that employs soft power tools for the most part; and it is an interventionism which changes the norm of sovereignty. It is increasingly regarded as legitimate to intervene in states where human rights and democracy are endangered; and this also holds for Western states, although they usually do not engage in each other's internal affairs. However, the case of Austria's 'shaming' marks a new era in how the sovereignty norm is viewed by the international community. 
In the field of international studies, one of the key questions is whether and how much independent impact international regimes and organisations wield. This is an important question in security and economic regimes. Here it has more or less been found that such non-state actors are important, sometimes as arenas, sometimes as actors. However, the question of whether these regimes and organisations also have an impact in the field of 'values and norms' such as human rights, has not been much studied. This book contributes to this debate by showing that the human rights regime itself has teeth - there are regime-specific powers in it, such as the supranational legal status of the European Convention of Human Rights (ECHR) and its court; the specificity and practical definitions of human rights and democracy in the OSCE texts; and the EU's stipulation of tailor-made demands on new entrants in this area. Thus, the human rights regime itself has various 'powers' built into it.

But the international organisations into which this regime is embedded also have 'teeth'. There are tools and powers that are specific to each organisation, and this makes for an independent impact of each one of them. Clearly states are the main driving forces and also 'owners' of international organisations, but the states do not account for the explanation of impact alone. In the OSCE it is the chairman who can influence the agenda-setting and often outcomes; in the EU both states and EU actors such as the Commission and the European Parliament have important roles. In the enlargement process, which is the key area where the EU has an impact in the human rights field today, the Commission has taken on the major role in defining demands and assessing progress vis-à-vis new entrants. Finally, in the Council of Europe the European Court of Human Rights clearly acts independently, but the new Commissioner for Human Rights also plays a similar role. Thus, in the analysis of impact in this study I seek to delineate not only the impact of human rights norms as opposed to other interests, but also the impact of regimes and international organisations as opposed to member states.

As State Secretary I was in charge of the OSCE chairmanship, the Council of Europe, and followed EU developments closely, although Norway is not a member. I also worked on the human rights politics and security policy in the UN system and in the Balkans, and led the Norwegian campaign to enter the Security Council in 2000. This gave me an opportunity to watch how human rights discourse and agendasetting became central to public arenas, but also how Realpolitik met this new world of values. Nothing I experienced dissuaded me in my 
conviction of the primacy of Realpolitik in the international system, but the conditions for exercising Realpolitik are changing. Values matter in new ways, based on a purely self-interested, instrumental logic which will be analysed below; but values also matter in some cases as deep convictions, as what I here term 'value-based' interests. A lot of foreign policy is carried out for altruistic reasons, or at least for reasons where the so-called 'national interest' is hard to ascertain. For example, aid to Bosnia may be defined as long-term security policy for Norway as it contributes to regional stability, and everyone recognises that human rights and democracy are essential prerequisites for stability; but the link between the self-interested 'national interest' and the benefit is a long-term one, much money down the road. Thus, I think we can find that the values of human rights and democracy really do matter to some actors, but also that the adoption of human rights and the impact of human rights can largely be explained by instrumental factors.

But this, importantly, does not mean that values matter less, rather that they matter more: they are 'hard' values, like 'hard' interests, if they matter for real power reasons. They are powerful, like economic or security interests are powerful - under certain circumstances. This is the central thesis of this book.

As my practical political work in all these fields evolved, I managed to take notes and to gather material for the book that was to be written later. The intensity of practical work and travel during those years made it impossible to write much, but it gave me a unique opportunity to be on the inside of, and to influence, political processes that an academic would never have been able to access. I was a decision-maker in many of the situations described and analysed in this study, ranging from the Kosovo war to the human rights dialogue with Cuba, which I initiated. My general academic interest in 'soft power', agenda-setting power and the new public diplomacy existed prior to taking political office, and I now had the chance to assess the real importance of these factors in international affairs. I also managed to maintain a certain level of academic contacts, and am particularly grateful to Professor Joseph Nye of Harvard's Kennedy School and his staff where I tested my ideas in a seminar in November 1999; and to the then Foreign Minister of Canada, Lloyd Axworthy, with whom inter alia I discussed 'human security' on his aircraft back from Yerevan after the state funeral due to the awful killings of half the Armenian government in October 1999. On this particular plane trip the British Europe Minister Keith Vaz also partook in the discussion with very interesting contribu- 
tions. Axworthy was also the architect behind the useful meetings of academics and practitioners in Ottawa on how to conceptualise and advance 'human security' - a security policy based on human rights. Now back in academia, he maintains, like myself, an acute interest in the practical usefulness of the academic work we do. I am grateful to these practitioners-cum-academics for the discussions we enjoyed on this theme.

From my time in political office I would like to acknowledge the importance of interaction and discussion about the problematic of this book with, inter alia; former Foreign Minister Knut Vollebæk, former State Secretary Wegger Strømmen; director-general Bjarne Lindstrøm, political directors Tarald Brautaset and Johan Løvald; OSCE director Kim Traavik as well as OSCE ambassador Kai Eide in the Norwegian Ministry of Foreign Affairs.

In the Council of Europe I had very useful meetings with the President of the European Court of Human Rights, Judge Luzius Wildhaber as well as his deputy president; with the Secretary-General of the Council of Europe, Walter Schwimmer and his deputy HansChristian Kruger; with the Human Rights Commissioner Alvaro GilRobles and with the President of the Parliamentary Assembly, Lord Russel-Johnston. The then Norwegian ambassador to the Council, Sten Lundbo, provided me with most of the written material on the COE in addition to setting up all the ministerial meetings I had in Strasbourg. His input has been very valuable for this book, and also for my interviews in the Polish Ministry of Foreign Affairs, as the current Norwegian ambassador to Poland.

During the year of Norway's OSCE chairmanship I was the deputy to the chairman, Mr Vollebæk. This gave me intimate and hands-on experience of the decision-making and impact of the organisation. Likewise, the OSCE staff in the secretariat in Vienna and the ODIHR staff in Warsaw, and in the various missions contributed a great deal to the information about OSCE's impact. I would like to mention in particular ambassador Robert Barry, head of mission in Bosnia; ambassador Gerard Stoudman, head of ODHIR; the High Commissioner for Minorities, Max van der Stoehl, and also the heads of mission in Albania, Kosovo, FYROM, Croatia and Kazakhstan. The OSCE is an organisation about which little is written and researched; thus, the field experience has been vital to procuring the input used in this study.

The role of so-called 'humanitarian intervention' was much discussed among policy-makers in NATO and at the UN during 1999. I am 
particularly grateful to UN civil servants in DPA and DPKO for fruitful discussions on peacekeeping and interventions under Security Council mandate; likewise I am indebted to former State Secretary Jan Eliasson of Sweden, now his country's ambassador to the USA, for his deep knowledge and also wisdom in these matters. A seminar in June 2000 at the Krusenberg estate outside of Stockholm gathered together the leading figure on the new value-based security policy, 'human security'; this was the result of Jan's initiative.

Finally, I have worked on the EU regularly for many years, and its human rights profile is now becoming a major part of its expanding foreign policy. On the question of its impact and on how to measure it, I have benefited from discussions with ARENA colleagues as well as with colleagues and students at the Department of Political Science at Lund University, Sweden, where I presented the arguments of this book in December 2000. Here in Oslo I also benefited from similar seminars in the autumn of 2000 at the Institute of Human Rights and at my own Institute of Political Science at Oslo University, where Professor Arild Underdal has been particularly helpful in his comments. 


\section{List of Abbreviations}

\begin{tabular}{|c|c|}
\hline CAP & Common Agricultural Policy \\
\hline CFSP & Common Foreign and Security Policy, \\
\hline CMEA & Council of Mutual Economic Assistance \\
\hline CSR & Corporate Social Responsibility \\
\hline DPA & Department of Political Affairs, UN \\
\hline DPKO & Department of Peace-Keeping Operations, UN \\
\hline ECHR & European Convention of Human Rights \\
\hline ECSU & European Coal and Steel Union \\
\hline EDC & European Defence Cooperation \\
\hline EMU & European Monetary Union \\
\hline EPC & European Political Cooperation \\
\hline EU & European Union \\
\hline FPÖ & Freiheitspartei Österreichs \\
\hline FRY & Former Republic of Yugoslavia \\
\hline FYROM & Former Yugoslav Republic of Macedonia \\
\hline G-24 & $\begin{array}{l}\text { The EU states and like-minded states working as } \\
\text { group to aid East-Central Europe }\end{array}$ \\
\hline G-77 & $\begin{array}{l}\text { Group of } 77 \text {, the UN grouping of developing } \\
\text { countries, now comprising } 144 \text { states }\end{array}$ \\
\hline HCNM & High Commissioner for National Minorities \\
\hline ICC & International Criminal Court, UN \\
\hline ICRC & International Committee of the Red Cross \\
\hline ICTY & International Criminal Tribunal for Yugoslavia \\
\hline IGC & Intergovernmental Conference \\
\hline $\mathrm{IO}$ & International Organisation \\
\hline JHA & Justice and Home Affairs \\
\hline KFOR & Kosovo Force \\
\hline KVM & Kosovo Verification Mission \\
\hline NATO & North Atlantic Treaty Organisation \\
\hline ODIHR & $\begin{array}{l}\text { Office for Democratic Institutions and Human } \\
\text { Rights (of the OSCE) }\end{array}$ \\
\hline OHR & Office Of the High Representative \\
\hline OSCE & Organisation for Security and Cooperation in Europe \\
\hline ÖVP & Österreichische Volkspartei \\
\hline PA & Partnership Agreement \\
\hline SEA & Single European Act \\
\hline
\end{tabular}


xviii List of Abbreviations

$\begin{array}{ll}\text { SFOR } & \text { Stability Force } \\ \text { TEU } & \text { Treaty on European Union } \\ \text { UDHR } & \text { Universal Declaration of Human Rights } \\ \text { UNHCR } & \text { United Nations High Commissioner for Refugees } \\ \text { UNGA } & \text { UN General Assembly } \\ \text { UNMIK } & \text { United Nations Mission in Kosovo } \\ \text { UNPROFOR } & \text { United Nations Protection Force } \\ \text { WEU } & \text { Western European Union } \\ \text { WTO } & \text { World Trade Organisation }\end{array}$

